\title{
ELEMENTARY SCHOOL EDUCATION IN INDIA: PERFORMANCE VERSUS EFFICIENCY ANALYSIS USING DEA
}

\author{
Dr. K M Chudasama
}

\section{ABSTRACT}

The robust education system being the driving force of economic prosperity, the question that: What determines educational efficiency? is of special significance. The school education is efficient, if with the optimum use of resources, its students can achieve the maximum academic result. School education differs in terms of resources (inputs) and achievements (outputs). It is possible that school education system may have less input but still be more efficient and vice versa. Thus, the discrepancy between lower and higher performance of school education can be better analysed by efficiency scale rather than the usual performance-based evaluation. This paper applies Data Envelopment Analysis (DEA) for efficiency appraisal of Elementary School Education in Indian States/Union Territories using State Report Cards/Flash Statistics database of NUEPA and compares derived Efficiency (DEA) Scores and Performance (Educational Development Index-EDI) Scores to inquire whether better educational (EDI) performance does necessarily turn out to be efficient (DEA) performance?

Keywords: Education, Performance, Efficiency, Data Envelopment Analysis, India.

The role of school education is crucial in augmenting the competitiveness of an economy. Enhancing the efficiency of a school education system becomes essential input for overall economic development. The robust education system being the driving force of economic prosperity, a question pertaining to: "what determines educational efficiency?" is of special significance (Tsakiridou \& Stergiou, 2014). The school education can be considered as efficient if with the optimum use of resources, its students can achieve the maximum academic result (other things reaming 
constant, ceteris paribus). The efficiency level of the school education is highly affected by its resources and academic practices (Raposo \& Menezes, 2011). The school resources are catalyst to the student achievement but differ most often in terms of facilities (inputs) as well as in attainments (outputs). It is possible that school education system may have less inputs in terms of academic staffs and physical facilities but still it might turn to be more efficient and vice versa (Nauzeer, Jaunky, \& Ramesh, 2018). Therefore, the discrepancy between lower and higher performance of school education can be better analysed by efficiency scale rather than the usual performance-based evaluation.

The importance of educational infrastructure in the growing economy like India is of prime concern due to the nation's increasing demand of educational facilities. In line with India's flagship program: Sarva Shiksha Abhiyan that was launched in 20002001 and placed emphasis on Universalization of Elementary Education (UEE), making free and compulsory education to the children of 6-14 years age group, all the states/union territories of India are putting substantial efforts to upgrade and achieve desired educational targets. This requires addressing the full utilization of existing capacities of school education in the most efficient manner apart from creating capacities by way of additional infrastructure and services. It is essential to continuously assess the efficiency of school education system that allows the decision makers to develop a better understanding of the competence and to provide useful insights for improvement of resource allocation. Therefore, the systematic appraisal of the efficiency of elementary school education in the States/Union Territories of India can reveal the States'/Union Territories' relative positions in terms of resource utilisation. This paper applies Data Envelopment Analysis (DEA) for efficiency appraisal of elementary school education in the State/Union Territory of India. Each State/Union Territory is considered as a Decision Making Unit (DMU) that uses similar inputs to attain similar outputs. The efficiency of DMU is determined relative to other DMUs, which are similar in terms of ability to transform inputs into desired outputs. Relatively efficient and relatively inefficient states/union territories for provision of elementary school education in India are identified. The DEA derived Efficiency Scores are compared with the NUEPA derived Education Development Index to determine the rank correlation between the Efficiency (scores) and 
Performance (index) as a feedback to the educational development initiatives in India.

The remainder of this paper is organised into further five sections. The second section explores the literature review, while the third section highlights Data Envelopment Analysis (DEA) Approach. The fourth section deals with efficiency analysis of elementary school education in states/union territories of India and derived efficiency is compared with education development index to assess the correlation between efficiency and performance, whereas the final section summarises the results and discussion.

Various studies on performance assessment and efficiency analysis of the public services (Lewin et al., 1982); post offices efficiency (Deprins et al., 1984); railway efficiency (Oum \& Chunyan, 1994); efficiency of schools (Ray, 1991). The efficiencies of airlines firms/industry (Distexhe \& Perelman, 1994; Good et al, 1995; Singh, 2011); efficiency of banks (Bhatacharya et al, 1997; Isik \& Hassan, 2002; Sufian, 2007); efficiency of hotel sector (Sigala, 2004); efficiency of construction firms (Minh \& Long, 2005); efficiency of state transport (Anjaneyulu, 2006); efficiency of tourism (Wober, 2007); efficiency of shipyards (Chudasama, 2010); efficiency of textile and apparel industry (Saricam \& Erdumlu, 2012); efficiency of power companies (Yang, 2013); efficiency of gas stations (Asayesh \& Raad, 2016); efficiency of ports (Chudasama, 2016a); efficiency of health care infrastructure (Sheikhzadeh Y et al, 2012; Chudasama, 2016b).

The efficiency analysis has been extensively used for monitoring the efficiency of school education systems in various countries. According to Eberts, Schwartz and Stone (1990) the school size may affect the efficiency, while Carty and Yaisawamg (1993) determined that public schools efficiency were related to the social-economic level of students' family. Duncombe, Miner and Ruggiero (1997) found that the size of the primary school has a positive effect on efficiency, whereas, Tyagi, Yadav and Singh (2000) determined that the larger the school size is, the higher the rate of efficiency, while Borge and Naper (2005) investigated the efficiency in the lower secondary schools in Norway. Educational efficiency appeared to be moderated largely by socioeconomic and parental factors beyond the control of local public 
schools (Conroy and Arguea, 2008). Zhang (2010) analysed elementary schools in Taiwan to investigate the relative efficiency by using two-stage DEA, while Agha et al (2011) applied DEA method to evaluate the relative technical efficiencies of academic departments at the Islamic University of Gaza. Nazarko (2014) analysed efficiency of public higher education Institutions using DEA method, while Kecek and Demirag (2016) applied DEA approach to primary schools in Kutahya province in Turkey to measure the relative efficiency. Whereas, Chudasama (2019) applied DEA to secondary and higher secondary schools of states of India and determined that states with better educational resources need not necessarily turn out to be efficient in terms of educational attainments.

\section{Data Envelopment Analysis (Dea) Approach}

DEA is a linear programming based non-parametric method to measure the relative efficiency of the decision making units (DMUs) that use similar multiple input(s) to produce similar multiple output(s). Charnes, Cooper and Rhodes (1978) extended the Farrell's (1957) work of measuring technical efficiency and introduced the data envelopment analysis, later on called as the DEA-CCR model, which investigated efficiency assuming constant returns to scales. Banker, Charnes and Cooper (1984) extended the CCR model which was called the DEA-BCC model that investigated efficiency assuming variable returns to scales. The DEA asserts that efficiency of any DMU is verified by its ability to convert inputs into outputs. According to this approach, the efficiency is always less than or equal to one due to some energy loss that occurs during the transformation process. The nonparametric computation in $D E A$, the prior knowledge of weights for the inputs and outputs is not required. In DEA, a single 'virtual' output and single 'virtual' input is obtained without estimating the production function. The ratio of sum of weighted outputs to the sum of weighted inputs is used to measure the efficiency. Efficiency = (weighted sum of outputs) / (weighted sum of inputs). The DMU to be currently measured is denoted by $\mathrm{DMU}_{\mathrm{i}}$, then its ratio of output to input will be represented as Efficiency of $\mathrm{DMU}_{\mathrm{i}}=$ $\frac{u_{1} y_{1 i}+w_{2} y_{2 i}+\cdots}{v_{1} x_{1 i}+v_{2} x_{2 i}+\cdots}$

Where $u_{1}=$ the weight given to output 1 and $y_{1 i}=$ amount of output 1 from DMU $i$ $v_{1}=$ the weight given to input 1 and $x_{1 i}=$ amount of input 1 to $\mathrm{DMU}$ 
[Note: $u \geq 0 ; v \geq 0$ and Efficiency is usually constrained to the range $(0,1)]$.

The efficiency of each DMU is measured once and therefore, " $n$ " optimizations are needed. If the DMU obtains an efficiency score of less than one, the unit is termed as relatively inefficient with respect to the other units in analysis and no other combination of weights can possibly make it efficient. If the unit obtains a score of one, the unit is relatively efficient (scope of improvement may still well exist), but the combination of weights makes it efficient. Likewise for each DMU, the ratio should be formulated. This means that each unit is allowed freedom in assigning the set of weights to its factor inputs, which will render the unit as efficient as possible within the constrained limit. An input-oriented efficiency model examines whether a firm is using the minimum inputs necessary to produce a given level of outputs and efficiency is measured by the maximum reduction in inputs which will still allow a given output level to be produced. If the goal is to minimise the use of inputs while keeping their output level constant, then an Input-Oriented model is appropriate. An output-oriented efficiency model examines whether a firm is achieving maximum output given the level of inputs and efficiency is measured by maximum increase in output which will still be possible at a given level of output. If the aim is to obtain the best results possible utilising the resources available (over which there is little or no control), the Output-Oriented version is appropriate.

The Basic DEA model categorizes the DMUs into efficient and inefficient units. Moreover, all efficient DMUs obtain the same efficiency score of 1 . In this case, it is impossible to distinguish between the efficient DMUs. To overcome this limitation, Andersen and Petersen (1993) developed the Super Efficiency DEA (SEDEA) to estimate the efficiencies of efficient DMUs. The SEDEA measures how much can the inputs be increased (or the outputs decreased) while not making the DMU inefficient. Due to the problem of infeasibility, there are differences in opinions regarding the application of super efficiency DEA, but it has been applied in case of constant returns to scales. Therefore, the notion that problem of infeasibility arises in case of SEDEA is limited to its applicability only in case of variable returns to scales and if there is zero in the data under analysis. Hence, use of SEDEA is widely acceptable for ranking DMUs in case of constant returns to scales and variables with non-zero 
data. The SEDEA is similar to DEA, but under SEDEA the efficient DMU under analysis is not included in the reference set to obtain its efficiency, while it is included in the reference set under DEA to obtain its efficiency. The difference between the DEA Model and the SEDEA model is that the DMU under evaluation is excluded from the reference set in SEDEA model which is based on a reference technology constructed from all other DMUs. To calculate the relative efficiency of the $D M U_{i}$, the Output-Oriented CCR-DEA Model can be presented as depicted in Table 1 below:

Table 1: DEA and Super Efficiency DEA Forms

\begin{tabular}{|l|l|}
\hline \multicolumn{1}{|c|}{ DEA Form } & Super Efficiency DEA Form \\
\hline $\max \sum_{k=1}^{s} v_{k} y_{k p}$ & $\max \sum_{k=1}^{s} v_{k} y_{k p}$ \\
s.t. $\sum_{j=1}^{m} u_{j} x_{j p}=1$ & s.t. $\sum_{j=1}^{m} u_{j} x_{j p}=1$ \\
$\sum_{k=1}^{s} v_{k} y_{k i}-\sum_{j=1}^{m} u_{j} x_{j i} \leq 0, \forall i$ & $\sum_{k=1}^{s} v_{k} y_{k i}-\sum_{j=1}^{m} u_{j} x_{j i} \leq 0, \forall i+p$ \\
$v_{k}, u_{j} \geq 0, \forall k, j$ & $v_{k}, u_{j} \geq 0, \forall k, j$
\end{tabular}

Where:

$k=1$ to $s \quad j=1$ to $m \quad i=1$ to $n$

$y_{k j}=$ amount of output $k$ produced by $\mathrm{DMU}_{i} \quad x_{i j}=$ amount of input $j$ utilized

by $\mathrm{DMU}_{i}$

$v_{k}=$ weight given to output $k \quad u_{j}=$ weight given to input $j$

$\forall i \neq p=$ excluding $\mathrm{DMU}$ from reference set

Therefore, the super efficiency score for that efficient DMU can take any value greater than or equal 1. As the efficiency scores are allowed to be greater than one, it is possible to rank the efficient DMUs on the basis of the super efficiency scores. (i.e. the higher the efficiency scores the higher the rank). In this case the scores for inefficient DMUs remain the same as in the basic DEA model. 


\section{Efficiency Analysis of Elementary School Education in India}

School Education System in India

Education in India is provided by public schools as well as private schools which are funded and controlled by three levels: central, state and local.Primary and Middle education is compulsory and free in India. It includes Lower Primary (Standards 1 to 5) and Upper Primary (Standards 6 to 8 ). Primary education usually begins at the age of 6 years with Middle/Upper Primary school education ending at the age of 14 years. Secondary education (Standards 9 and 10) usually begins at the age of 15 years and lasts usually until Higher Secondary education (Standards 11 and 12) ending at the age of about 18 years.

"Sarva Siksha Abhiyan" (SSA) with the objective of "Education for All Movement" is initiated by the Government of India for universalisation of elementary education in the country since 2000-01. The program is mandated in the constitution making education free to children of ages 6-14 and a fundamental right. As per the National University of Educational Planning and Administration (NUEPA) database of 2017, there have been $14,67,680$ schools in elementary education having $76,06,638$ class rooms with $80,62,878$ teachers for $18,98,87,015$ students across all the 29 states and 7 union territories in India. Primary education in India acts as a torch bearer for higher education to acquire skills for employment in India.

\section{The Input and Output Variables}

The data pertaining to input and output variables of elementary schools of states/union territories of India has been sourced from the State Report Cards 201011 to 2014-15 and Flash Statistics 2010-11 to 2014-15 of National University of Educational Planning and Administration (NUEPA). As the output of a school education depends on the use of available input resources, the main objective of school education is assumed to be maximization of the output, given the inputs. The Input and Output variables are given in the Table 2 below:

Table 2: Output and Input Variables of Elementary School Education in India

\begin{tabular}{|l|l|l|}
\hline Variable Type & Component & \multicolumn{1}{c|}{ Variables } \\
\hline $\begin{array}{l}\text { Output } \\
\text { Variables }\end{array}$ & Outcome & $\begin{array}{l}\text { Total Enrolment, } \\
\% \text { of Girls' Enrolment }\end{array}$ \\
\hline
\end{tabular}


Towards Excellence: An Indexed, Refereed \& Peer Reviewed Journal of Higher Education / Dr. K M Chudasama / Page 59-78

\begin{tabular}{|l|l|l|}
\hline \multirow{5}{*}{ Input } & & $\begin{array}{l}\text { Transition Rate from Primary to Upper Primary } \\
\text { level }\end{array}$ \\
\hline \multirow{3}{*}{ Variables } & Access & $\begin{array}{l}\text { Total Schools } \\
\text { \% Schools Approachable by All Weather Road } \\
\text { Ratio of Primary to Upper Primary Schools/ } \\
\text { Sections }\end{array}$ \\
\cline { 3 - 4 } & \multirow{3}{*}{ Infrastructure } & $\begin{array}{l}\text { Total Class Rooms } \\
\text { Schools with Separate Girls Toilet } \\
\text { Schools with Drinking Water } \\
\text { Schools with Electricity Connectivity }\end{array}$ \\
\cline { 2 - 4 } & Teachers & $\begin{array}{l}\text { Total Teachers } \\
\text { \% Professionally Qualified / Trained Teachers }\end{array}$ \\
\hline
\end{tabular}

\section{Empirical Analysis}

Efficiency Measurement System (EMS) Software, Version 1.3 is employed to derive the efficiency estimates of Elementary School Education in total 36 states/union territories of India. DEA-CCR Model is applied to derive the relative efficiency of elementary School Education in states/union territories under analysis. On the basis of derived efficiency estimates, the relatively efficient and relatively inefficient states/union territories in terms of Elementary School Education are identified. The estimated efficiency scores also reveal the extent to which an inefficient unit is made efficient through the proportional increase of its outputs, while the inputs proportions remain unchanged. The efficiency scores states/union territories (for Elementary School Education) are presented in Table 3 below.

Table 3: Efficiency Summary of Elementary School Education in India*

\begin{tabular}{|l|c|c|c|c|c|c|c|c|c|c|}
\hline State/UT & \multicolumn{2}{|c|}{$2010-11$} & \multicolumn{2}{|c|}{$2011-12$} & \multicolumn{2}{c|}{$2012-13$} & \multicolumn{2}{c|}{$2013-14$} & \multicolumn{2}{|c|}{$2014-15$} \\
\hline A \& N Islands & 0.61 & & 0.92 & & 0.95 & 0.82 & & 0.33 & \\
\hline Andhra Pradesh & 1.04 & $\mathrm{E}$ & 1.01 & $\mathrm{E}$ & 0.94 & & 0.85 & & 1.03 & $\mathrm{E}$ \\
\hline $\begin{array}{l}\text { Arunachal } \\
\text { Pradesh }\end{array}$ & 0.69 & & 0.67 & & 0.69 & & 0.58 & & 0.86 & \\
\hline Assam & NA & & 0.96 & & 0.85 & & 0.88 & & 1.07 & $\mathrm{E}$ \\
\hline Bihar & 0.40 & & 0.20 & & 0.21 & & 0.34 & & 1.08 & $\mathrm{E}$ \\
\hline
\end{tabular}


Towards Excellence: An Indexed, Refereed \& Peer Reviewed Journal of Higher Education / Dr. K M Chudasama / Page 59-78

\begin{tabular}{|c|c|c|c|c|c|c|c|c|c|c|}
\hline Chandigarh & NA & & 0.44 & & NA & & NA & & 1.09 & $E$ \\
\hline Chhattisgarh & 0.87 & & 0.93 & & 1.07 & $E$ & 1.11 & $E$ & 0.76 & \\
\hline D \& N Haveli & 0.45 & & 0.83 & & 0.75 & & 0.69 & & 0.93 & \\
\hline Daman \& Diu & 0.67 & & 0.75 & & NA & & NA & & 0.98 & \\
\hline Delhi & NA & & 0.56 & & $\mathrm{NA}$ & & NA & & 1.05 & $E$ \\
\hline Goa & 0.73 & & 1.04 & $E$ & NA & & NA & & NA & \\
\hline Gujarat & 0.84 & & 0.97 & & 0.83 & & 0.84 & & 1.02 & $E$ \\
\hline Haryana & 0.80 & & 1.02 & $E$ & 0.92 & & 0.27 & & 0.94 & \\
\hline $\begin{array}{l}\text { Himachal } \\
\text { Pradesh }\end{array}$ & 1.01 & $E$ & 1.05 & $E$ & 1.08 & $E$ & 1.10 & $E$ & 0.92 & \\
\hline $\begin{array}{l}\text { Jammu \& } \\
\text { Kashmir }\end{array}$ & 0.90 & & 0.86 & & 0.87 & & 0.89 & & 0.71 & \\
\hline Jharkhand & 0.67 & & 1.01 & $\mathrm{E}$ & 0.68 & & 0.74 & & 1.05 & $E$ \\
\hline Karnataka & 1.01 & $E$ & 0.88 & & 1.09 & $E$ & 1.06 & $E$ & 0.97 & \\
\hline Kerala & NA & & 0.86 & & NA & & NA & & 0.56 & \\
\hline Lakshadweep & 0.09 & & 0.37 & & 0.13 & & 0.14 & & 0.59 & \\
\hline Madhya Pradesh & 0.92 & & 0.96 & & 0.87 & & 0.71 & & 1.13 & $E$ \\
\hline Maharashtra & 0.80 & & 0.96 & & 0.96 & & 0.96 & & 0.96 & \\
\hline Manipur & 0.88 & & 0.93 & & 0.97 & & 0.82 & & 0.85 & \\
\hline Meghalaya & 0.49 & & 0.71 & & NA & & NA & & 0.74 & \\
\hline Mizoram & NA & & 0.92 & & 0.83 & & 0.72 & & 1.13 & $E$ \\
\hline Nagaland & 0.78 & & 0.72 & & 0.72 & & 0.46 & & 0.53 & \\
\hline Orissa & 0.86 & & 0.97 & & 0.93 & & 0.95 & & 0.66 & \\
\hline Puducherry & NA & & 0.86 & & 0.64 & & NA & & 1.03 & $E$ \\
\hline Punjab & NA & & 1.10 & $E$ & 1.03 & $E$ & 1.03 & $E$ & 0.72 & \\
\hline Rajasthan & 0.78 & & 0.97 & & 0.85 & & 0.90 & & 0.55 & \\
\hline Sikkim & 0.75 & & 0.36 & & 0.74 & & 0.37 & & 0.90 & \\
\hline Tamil Nadu & 1.09 & $E$ & 1.02 & $E$ & 1.09 & $\mathrm{E}$ & 1.07 & $E$ & 1.20 & $E$ \\
\hline Tripura & 0.72 & & 0.72 & & 0.77 & & 0.81 & & 0.94 & \\
\hline Uttar Pradesh & 0.54 & & 0.21 & & 0.44 & & 0.42 & & 0.88 & \\
\hline Uttaranchal & 1.04 & $E$ & 1.05 & $E$ & 1.11 & $E$ & 1.11 & $E$ & 1.00 & $E$ \\
\hline West Bengal & 1.10 & $E$ & 0.99 & & 0.99 & & 1.02 & $E$ & 0.93 & \\
\hline
\end{tabular}

Note: * Derived using Efficiency Measurement System (EMS) Software, Version 1.3. 
Towards Excellence: An Indexed, Refereed \& Peer Reviewed Journal of Higher Education / Dr. K M Chudasama / Page 59-78

NA: Data Not Available, E: Efficient.

\section{Comparison of Performance (Index) and Efficiency (Scores)}

The Educational Development Index (EDI) in Flash Statistics is published every year by NUEPA. The Educational Development Index is computed considering the components/indicators comprising Access, Infrastructure, Teachers and Outcomes, which are largely similar to those inputs and outputs variables used in Data Envelopment Analysis. The EDI Scores reveal the relative performance of the States/Union Territories in context of Elementary School Education, whereas the DEA Scores reveal the relative efficiency of the States/Union Territories in context of Elementary School Education. Higher the score depicts the better performance/more efficiency and attains the better rank. The summary of DEA Scores with its Ranking and EDI Scores with its Ranking is presented in the Table 4 below.

Table 4: Efficiency and Performance of Elementary School Education in India*

\begin{tabular}{|c|c|c|c|c|c|c|c|c|c|c|c|c|c|}
\hline \multirow[b]{2}{*}{ Sr. } & \multirow[b]{2}{*}{ tate } & \multicolumn{4}{|c|}{$2010-11$} & \multicolumn{4}{|c|}{$2011-12$} & \multicolumn{4}{|c|}{$2012-13$} \\
\hline & & \begin{tabular}{|c} 
DEA \\
Scor \\
e
\end{tabular} & \begin{tabular}{|c|} 
DEA \\
Ran \\
$k$
\end{tabular} & $\begin{array}{c}E \text { EDI }^{*} \\
\text { Scor } \\
\text { e }\end{array}$ & $\begin{array}{c}\text { EDI } \\
\text { Ran } \\
k\end{array}$ & \begin{tabular}{|c|} 
DEA \\
Scor \\
$\mathrm{e}$
\end{tabular} & $\begin{array}{c}\text { DEA } \\
\text { Ran } \\
k\end{array}$ & $\mid \begin{array}{c}\text { EDI } \\
\text { Scor } \\
\mathrm{e}\end{array}$ & $\begin{array}{c}\text { EDI } \\
\text { Ran } \\
k\end{array}$ & \begin{tabular}{|c|} 
DEA \\
Scor \\
$\mathrm{e}$
\end{tabular} & $\begin{array}{l}\text { DEA } \\
\text { Rank }\end{array}$ & $\begin{array}{c}E D I^{*} \\
\text { Scor } \\
e\end{array}$ & $\begin{array}{l}\text { EDI } \\
\text { Rank }\end{array}$ \\
\hline 1 & A \& N Islands & 0.61 & 23 & 0.72 & 12 & 0.92 & 18 & 0.59 & 16 & 0.95 & 10 & 0.60 & 13 \\
\hline 2 & Andhra Pradesh & 1.04 & 4 & 0.77 & 5 & 1.01 & 7 & 0.60 & 15 & 0.94 & 11 & 0.58 & 19 \\
\hline 3 & $\begin{array}{c}\text { Arunachal } \\
\text { Pradesh }\end{array}$ & 0.69 & 20 & 0.60 & 25 & 0.67 & 29 & 0.49 & 31 & 0.69 & 24 & 0.59 & 15 \\
\hline 4 & Assam & $\mathrm{NA}$ & NA & NA & $\mathrm{NA}$ & 0.96 & 15 & 0.45 & 35 & 0.85 & 17 & 0.53 & 27 \\
\hline 5 & Bihar & 0.40 & 27 & 0.51 & 28 & 0.20 & 35 & $\mid 0.47$ & 33 & 0.21 & 28 & 0.53 & 25 \\
\hline 6 & Chandigarh & NA & NA & NA & NA & 0.44 & 31 & 0.62 & 10 & NA & NA & NA & NA \\
\hline 7 & Chhattisgarh & 0.87 & 10 & 0.61 & 20 & 0.93 & 16 & 0.51 & 28 & 1.07 & 5 & 0.58 & 18 \\
\hline 8 & D \& N Haveli & 0.45 & 26 & 0.66 & 16 & 0.83 & 24 & 0.60 & 14 & 0.75 & 21 & 0.61 & 11 \\
\hline 9 & Daman \& Diu & 0.67 & 21 & 0.80 & 3 & 0.75 & 25 & 0.68 & 5 & NA & NA & NA & $\mathrm{NA}$ \\
\hline 10 & Delhi & $\mathrm{NA}$ & NA & NA & $\mathrm{NA}$ & 0.56 & 30 & 0.66 & 6 & NA & NA & NA & NA \\
\hline 11 & Goa & 0.73 & 18 & 0.75 & 7 & 1.04 & 4 & 0.56 & 21 & NA & NA & NA & NA \\
\hline 12 & Gujarat & 0.84 & 12 & 0.74 & 9 & \begin{tabular}{|l|}
0.97 \\
\end{tabular} & 12 & 0.63 & 9 & 0.83 & 19 & 0.59 & 14 \\
\hline 13 & Haryana & 0.80 & 13 & 0.76 & 6 & 1.02 & 5 & 0.59 & 17 & 0.92 & 13 & 0.59 & 17 \\
\hline 14 & Himachal & 1.01 & 5 & 0.74 & 8 & 1.05 & 2 & $\mid 0.62$ & 11 & 1.08 & 4 & 0.63 & 10 \\
\hline
\end{tabular}


Towards Excellence: An Indexed, Refereed \& Peer Reviewed Journal of Higher Education / Dr. K M Chudasama / Page 59-78

\begin{tabular}{|c|c|c|c|c|c|c|c|c|c|c|c|c|c|}
\hline & Prad & & & & & & & & & & & & \\
\hline 15 & $\begin{array}{r}\text { Jammu \& } \\
\text { Kashmir }\end{array}$ & 0.90 & 8 & 0.68 & 13 & 0.86 & 21 & 0.58 & 18 & 0.87 & 14 & 0.60 & 12 \\
\hline 16 & Jharkhand & 0.67 & 22 & 0.53 & 27 & 1.01 & 8 & 0.45 & 34 & 0.68 & 25 & 0.45 & 29 \\
\hline 17 & Karnataka & 1.01 & 6 & 0.73 & 10 & 0.88 & 20 & 0.69 & 2 & 1.09 & 2 & 0.66 & 5 \\
\hline 18 & Kerala & NA & NA & NA & NA & 0.86 & 23 & 0.64 & 7 & NA & $\mathrm{NA}$ & NA & NA \\
\hline 19 & Lakshadweep & 0.09 & 28 & 0.85 & 1 & 0.37 & 32 & 0.72 & 1 & 0.13 & 29 & 0.71 & 1 \\
\hline 20 & $\begin{array}{l}\text { Madhya } \\
\text { Pradesh }\end{array}$ & 0.92 & 7 & 0.59 & 26 & 0.96 & 14 & 0.52 & 26 & 0.87 & 15 & 0.55 & 23 \\
\hline 21 & Maharashtra & 0.80 & 14 & 0.72 & 11 & 0.96 & 13 & 0.63 & 8 & 0.96 & 9 & 0.64 & 7 \\
\hline 22 & Manipur & 0.88 & 9 & 0.62 & 19 & 0.93 & 17 & 0.53 & 24 & 0.97 & 8 & 0.63 & 8 \\
\hline 23 & Meghalaya & 0.49 & 25 & 0.60 & 24 & 0.71 & 28 & 0.52 & 27 & NA & NA & NA & NA \\
\hline 24 & Mizoram & NA & NA & NA & NA & 0.92 & 19 & 0.58 & 19 & 0.83 & 18 & 0.63 & 9 \\
\hline 25 & Nagaland & 0.78 & 16 & 0.67 & 14 & 0.72 & 27 & 0.49 & 30 & 0.72 & 23 & 0.57 & 21 \\
\hline 26 & Orissa & 0.86 & 11 & 0.61 & 22 & 0.97 & 10 & 0.54 & 22 & 0.93 & 12 & 0.57 & 22 \\
\hline 27 & Puducherry & NA & NA & NA & NA & 0.86 & 22 & 0.68 & 4 & 0.64 & 26 & 0.70 & 2 \\
\hline 28 & Punjab & NA & NA & NA & NA & 1.10 & 1 & 0.61 & 13 & 1.03 & 6 & 0.65 & 6 \\
\hline 29 & Rajasthan & 0.78 & 15 & 0.62 & 18 & 0.97 & 11 & 0.54 & 23 & 0.85 & 16 & 0.57 & 20 \\
\hline 30 & Sikkim & 0.75 & 17 & 0.80 & 4 & 0.36 & 33 & 0.62 & 12 & 0.74 & 22 & 0.67 & 4 \\
\hline 31 & Tamil Nadu & 1.09 & 2 & 0.82 & 2 & 1.02 & 6 & 0.69 & 3 & 1.09 & 3 & 0.68 & 3 \\
\hline 32 & Tripura & 0.72 & 19 & 0.63 & 17 & 0.72 & 26 & 0.52 & 25 & 0.77 & 20 & 0.55 & 24 \\
\hline 33 & Uttar Pradesh & 0.54 & 24 & 0.61 & 23 & 0.21 & 34 & 0.47 & 32 & 0.44 & 27 & 0.51 & 28 \\
\hline 34 & Uttaranchal & 1.04 & 3 & 0.67 & 15 & 1.05 & 3 & 0.57 & 20 & 1.11 & 1 & 0.59 & 16 \\
\hline 35 & West Bengal & 1.10 & 1 & 0.61 & 21 & 0.99 & 9 & 0.50 & 29 & 0.99 & 7 & 0.53 & 26 \\
\hline \multicolumn{2}{|c|}{ Rank Correlation } & \multicolumn{4}{|c|}{0.179} & \multicolumn{4}{|c|}{0.012} & \multicolumn{4}{|c|}{0.207} \\
\hline
\end{tabular}

Note: NA: Data Not Available. * Adopted from Flash Statistics-EDI \& Rank derived by NUEPA.

Table 4: Efficiency and Performance of Elementary School Education in India*

\begin{tabular}{|c|c|c|c|c|c|c|c|c|c|}
\hline \multicolumn{9}{|c|}{ Continue... } \\
\hline & & \multicolumn{3}{|c|}{$2013-14$} & \multicolumn{3}{|c|}{$2014-15$} \\
\hline Sr. & \multirow{3}{*}{ State } & DEA & DEA & EDI* & EDI & DEA & DEA & EDI & EDI \\
& & Scor & Rank & Scor & Rank & Scor & Rank & Scor & Rank \\
& e & e & Rank & & e & \\
\hline
\end{tabular}


Towards Excellence: An Indexed, Refereed \& Peer Reviewed Journal of Higher Education / Dr. K M Chudasama / Page 59-78

\begin{tabular}{|c|l|c|c|c|c|c|c|c|c|}
1 & A \& N Islands & 0.82 & 16 & 0.67 & 8 & 0.33 & 34 & 0.66 & 12 \\
\hline 2 & Andhra Pradesh & 0.85 & 13 & 0.60 & 14 & 1.03 & 10 & 0.58 & 23 \\
\hline 3 & $\begin{array}{l}\text { Arunachal } \\
\text { Pradesh }\end{array}$ & 0.58 & 22 & 0.55 & 22 & 0.86 & 23 & 0.57 & 24 \\
\hline 4 & Assam & 0.88 & 12 & 0.52 & 23 & 1.07 & 6 & 0.49 & 31 \\
\hline 5 & Bihar & 0.34 & 26 & 0.49 & 27 & 1.08 & 5 & 0.50 & 30 \\
\hline 6 & Chandigarh & NA & NA & NA & NA & 1.09 & 4 & 0.68 & 9 \\
\hline 7 & Chhattisgarh & 1.11 & 2 & 0.57 & 20 & 0.76 & 25 & 0.56 & 25 \\
\hline 8 & D \& N Haveli & 0.69 & 21 & 0.61 & 13 & 0.93 & 18 & 0.60 & 19 \\
\hline 9 & Daman \& Diu & NA & NA & NA & NA & 0.98 & 13 & 0.65 & 14 \\
\hline 10 & Delhi & NA & NA & NA & NA & 1.05 & 7 & 0.72 & 2 \\
\hline 11 & Goa & NA & NA & NA & NA & NA & NA & NA & NA \\
\hline 12 & Gujarat & 0.84 & 14 & 0.70 & 6 & 1.02 & 11 & 0.68 & 7 \\
\hline 13 & Haryana & 0.27 & 27 & 0.65 & 10 & 0.94 & 16 & 0.64 & 15 \\
\hline 14 & $\begin{array}{l}\text { Himachal } \\
\text { Pradesh }\end{array}$ & 1.10 & 3 & 0.71 & 3 & 0.92 & 20 & 0.70 & 5 \\
\hline 15 & $\begin{array}{l}\text { Jammu \& } \\
\text { Kashmir }\end{array}$ & 0.89 & 11 & 0.57 & 21 & 0.71 & 28 & 0.54 & 27 \\
\hline 16 & Jharkhand & 0.74 & 18 & 0.51 & 26 & 1.05 & 8 & 0.49 & 33 \\
\hline 17 & Karnataka & 1.06 & 5 & 0.71 & 4 & 0.97 & 14 & 0.70 & 4 \\
\hline 18 & Kerala & NA & NA & NA & NA & 0.56 & 31 & 0.66 & 11 \\
\hline 19 & Lakshadweep & 0.14 & 28 & 0.74 & 1 & 0.59 & 30 & 0.70 & 3 \\
\hline 20 & $\begin{array}{l}\text { Madhya } \\
\text { Pradesh }\end{array}$ & 0.71 & 20 & 0.52 & 24 & 1.13 & 3 & 0.49 & 32 \\
\hline 21 & Maharashtra & 0.96 & 8 & 0.65 & 9 & 0.96 & 15 & 0.66 & 13 \\
\hline 22 & Manipur & 0.82 & 15 & 0.63 & 12 & 0.85 & 24 & 0.60 & 18 \\
\hline 23 & Meghalaya & NA & NA & NA & NA & 0.74 & 26 & 0.54 & 28 \\
\hline 24 & Mizoram & 0.72 & 19 & 0.60 & 16 & 1.13 & 2 & 0.64 & 16 \\
\hline 25 & Nagaland & 0.46 & 23 & 0.59 & 18 & 0.53 & 33 & 0.55 & 26 \\
\hline 26 & Orissa & 0.95 & 9 & 0.60 & 15 & 0.66 & 29 & 0.60 & 20 \\
\hline 27 & Puducherry & NA & NA & NA & NA & 1.03 & 9 & 0.72 & 1 \\
\hline 28 & Punjab & 1.03 & 0.69 & 7 & 0.72 & 27 & 0.67 & 10 \\
\hline 29 & Rajasthan & 0.90 & 17 & 0.55 & 32 & 0.59 & 22 \\
\hline
\end{tabular}


Towards Excellence: An Indexed, Refereed \& Peer Reviewed Journal of Higher Education / Dr. K M

Chudasama / Page 59-78

\begin{tabular}{|c|l|c|c|c|c|c|c|c|c|}
30 & Sikkim & 0.37 & 25 & 0.72 & 2 & 0.90 & 21 & 0.68 & 8 \\
\hline 31 & Tamil Nadu & 1.07 & 4 & 0.70 & 5 & 1.20 & 1 & 0.69 & 6 \\
\hline 32 & Tripura & 0.81 & 17 & 0.58 & 19 & 0.94 & 17 & 0.60 & 21 \\
\hline 33 & Uttar Pradesh & 0.42 & 24 & 0.46 & 28 & 0.88 & 22 & 0.46 & 34 \\
\hline 34 & Uttaranchal & 1.11 & 1 & 0.64 & 11 & 1.00 & 12 & 0.63 & 17 \\
\hline 35 & West Bengal & 1.02 & 7 & 0.52 & 25 & 0.93 & 19 & 0.51 & 29 \\
\hline \multicolumn{3}{|c|}{ Rank Correlation } & \multicolumn{3}{|c|}{0.194} & \multicolumn{5}{|c|}{050} \\
\hline
\end{tabular}

Note: NA: Data Not Available. * Adopted from Flash Statistics-EDI \& Rank derived by NUEPA.

The higher the score of efficiency exhibits the greater efficiency. However, efficiency score below 1 depict the relatively inefficient States/Union Territories which do not optimally utilise the given resources to attain the greater output, while the efficiency score of 1 and above depict the relatively efficient States/Union Territories which do optimally utilise the given resources to attain the greater output (however, the possibility of improvement always exist). On the other hand higher score of EDI reveal the better performance of States/Union Territories in terms of attaining the desirable targets. However, if the States/Union Territories having higher EDI score and revealing better performance need not necessarily turn out to be efficient and vice versa.

\section{Result and Discussion}

On the basis of the efficiency scores obtained for Elementary School Education in India, it is revealed that Tamil Nadu turned out to be highly efficient in all the 5 years under analysis; while, Himachal Pradesh and Uttaranchal turned out to be highly efficient in 4 out of 5 years under analysis; whereas, Andhra Pradesh, Karnataka and Punjab turned out to be highly efficient in 3 out of 5 years under analysis; and Chhattisgarh, Jharkhand and West Bengal turned out to be relatively efficient in 2 out of 5 years under analysis. However, Assam, Bihar, Chandigarh, Delhi, Goa, Gujarat, Haryana, Madhya Pradesh, Mizoram and Puducherry turned out to be efficient in 1 out of 5 years under analysis, while Andaman \& Nikobar Islands, Arunachal Pradesh, Daman \& Diu, Dadra \& Nagar Haveli, Jammu \& Kashmir, Kerala, Lakshadweep, Maharashtra, Manipur, Meghalaya, Nagaland, Orissa, Rajasthan, 
Towards Excellence: An Indexed, Refereed \& Peer Reviewed Journal of Higher Education / Dr. K M Chudasama / Page 59-78

Sikkim, Tripura and Uttar Pradesh never turned out to be efficient in all the 5 years under analysis. The summary of DEA rankings of most efficient States/Union Territories and corresponding EDI rankings of those States/Union Territories are given in the Table 5 below.

Table 5: DEA Ranking of Efficient States/Union Territories\& Corresponding EDI

Ranking

\begin{tabular}{|c|c|c|c|c|c|c|c|c|c|c|c|}
\hline \multirow{3}{*}{ Sr. } & \multirow{3}{*}{ State } & \multicolumn{2}{|c|}{$2010-11$} & \multicolumn{2}{|c|}{$2011-12$} & \multicolumn{2}{|c|}{$2012-13$} & \multicolumn{2}{|c|}{$2013-14$} & \multicolumn{2}{|c|}{$2014-15$} \\
\hline & & DEA & EDI & DEA & EDI & DEA & EDI & DEA & EDI & DEA & EDI \\
\hline & & Rank & Rank & Rank & Rank & Rank & Rank & Rank & Rank & Rank & Rank \\
\hline 1 & Tamil Nadu & $2^{*}$ & 2 & $6^{*}$ & 3 & $3^{*}$ & 3 & $4^{*}$ & 5 & $1^{*}$ & 6 \\
\hline 2 & $\begin{array}{l}\text { Himachal } \\
\text { Pradesh }\end{array}$ & $5^{*}$ & 8 & $2^{*}$ & 11 & $4^{*}$ & 10 & $3^{*}$ & 3 & 20 & 5 \\
\hline 3 & Uttaranchal & $3^{*}$ & 15 & $3^{*}$ & 20 & $1^{*}$ & 16 & $1^{*}$ & 11 & 12 & 17 \\
\hline 4 & $\begin{array}{l}\text { Andhra } \\
\text { Pradesh }\end{array}$ & $4^{*}$ & 5 & $7^{*}$ & 15 & 11 & 19 & 13 & 14 & $10^{*}$ & 23 \\
\hline 5 & Karnataka & $6^{*}$ & 10 & 20 & 2 & $2^{*}$ & 5 & $5^{*}$ & 4 & 14 & 4 \\
\hline 6 & Punjab & NA & NA & $1^{*}$ & 13 & $6^{*}$ & 6 & $6^{*}$ & 7 & 27 & 10 \\
\hline 7 & Chhattisgarh & 10 & 20 & 16 & 28 & $5^{*}$ & 18 & $2^{*}$ & 20 & 25 & 25 \\
\hline 8 & Jharkhand & 22 & 27 & $8^{*}$ & 34 & 25 & 29 & 18 & 26 & $8^{*}$ & 33 \\
\hline 9 & West Bengal & $1^{*}$ & 21 & 9 & 29 & 7 & 26 & $7^{*}$ & 25 & 19 & 29 \\
\hline 10 & Assam & NA & NA & 15 & 35 & 17 & 27 & 12 & 23 & $6^{*}$ & 31 \\
\hline 11 & Bihar & 27 & 28 & 35 & 33 & 28 & 25 & 26 & 27 & $5^{*}$ & 30 \\
\hline 12 & Chandigarh & NA & NA & 31 & 10 & NA & NA & NA & NA & $4^{*}$ & 9 \\
\hline 13 & Delhi & NA & NA & 30 & 6 & NA & NA & NA & NA & $7^{*}$ & 2 \\
\hline 14 & Goa & 18 & 7 & $4^{*}$ & 21 & NA & NA & NA & NA & NA & NA \\
\hline 15 & Gujarat & 12 & 9 & 12 & 9 & 19 & 14 & 14 & 6 & $11^{*}$ & 7 \\
\hline 17 & Haryana & 13 & 6 & $5^{*}$ & 17 & 13 & 17 & 27 & 10 & 16 & 15 \\
\hline 18 & $\begin{array}{l}\text { Madhya } \\
\text { Pradesh }\end{array}$ & 7 & 26 & 14 & 26 & 15 & 23 & 20 & 24 & $3^{*}$ & 32 \\
\hline 19 & Mizoram & NA & NA & 19 & 19 & 18 & 9 & 19 & 16 & $2^{*}$ & 16 \\
\hline 20 & Puducherry & NA & NA & 22 & 4 & 26 & 2 & NA & NA & 9* & 1 \\
\hline
\end{tabular}

Note: * E: Efficient. NA: Data Not Available, 
On the basis of the performance (EDI) scores for Elementary School Education in India, it is revealed that Karnataka, Lakshadweep and Tamil Nadu turned out to be amongst top 10 performing States/Union Territories in all the 5 years under analysis; while, Gujarat, Himachal Pradesh and Sikkim turned out to be amongst top 10 performing States/Union Territories in 4 out of 5 years under analysis; whereas, Maharashtra, Puducherry and Punjab turned out to be amongst top 10 performing States/Union Territories in 3 out of 5 years under analysis. Chandigarh, Daman \& Diu, Delhi and Haryana turned out to be amongst top 10 performing States/Union Territories in 2 out of 5 years under analysis, while, Andaman \& Nikobar Islands, Andhra Pradesh, Goa, Kerala, Manipur and Mizoram turned out to be amongst top 10 performing States/Union Territories in 1 out of 5 years under analysis; whereas, Arunachal Pradesh, Assam, Bihar, Chhattisgarh, Dadra \& Nagar Haveli, Jammu \& Kashmir, Jharkhand, Madhya Pradesh, Meghalaya, Nagaland, Orissa, Rajasthan, Tripura, Uttar Pradesh, Uttaranchal and West Bengal never turned out to be amongst top 10 performing States/Union Territories in any of the 5 years under analysis as shown in Table 6.

Table 6: EDI Ranking of Top Performing States/Union Territories\& Corresponding DEA Ranking

\begin{tabular}{|c|c|c|c|c|c|c|c|c|c|c|c|}
\hline \multirow{3}{*}{ Sr. } & \multirow{3}{*}{ State } & \multicolumn{2}{|c|}{$2010-11$} & \multicolumn{2}{|c|}{$2011-12$} & \multicolumn{2}{|c|}{$2012-13$} & \multicolumn{2}{|c|}{ 2013-14 } & \multicolumn{2}{|c|}{$2014-15$} \\
\hline & & EDI & DEA & EDI & DEA & EDI & DEA & EDI & DEA & EDI & DEA \\
\hline & & Rank & Rank & Rank & Rank & Rank & Rank & Rank & Rank & Rank & Rank \\
\hline 1 & Karnataka & 10 & 6 & 2 & 20 & 5 & 2 & 4 & 5 & 4 & 14 \\
\hline 2 & Lakshadweep & 1 & 28 & 1 & 32 & 1 & 29 & 1 & 28 & 3 & 30 \\
\hline 3 & Tamil Nadu & 2 & 2 & 3 & 6 & 3 & 3 & 5 & 4 & 6 & 1 \\
\hline 4 & Gujarat & 9 & 12 & 9 & 12 & $14^{*}$ & 19 & 6 & 14 & 7 & 11 \\
\hline 5 & $\begin{array}{l}\text { Himachal } \\
\text { Pradesh }\end{array}$ & 8 & 5 & $11^{*}$ & 2 & 10 & 4 & 3 & 3 & 5 & 20 \\
\hline 6 & Sikkim & 4 & 17 & $12^{*}$ & 33 & 4 & 22 & 2 & 25 & 8 & 21 \\
\hline 7 & Maharashtra & $11^{*}$ & 14 & 8 & 13 & 7 & 9 & 9 & 8 & $13^{*}$ & 15 \\
\hline 8 & Puducherry & NA & NA & 4 & 22 & 2 & 26 & NA & NA & 1 & 9 \\
\hline 9 & Punjab & NA & NA & $13^{*}$ & 1 & 6 & 6 & 7 & 6 & 10 & 27 \\
\hline 10 & Chandigarh & NA & NA & 10 & 31 & NA & NA & NA & NA & 9 & 4 \\
\hline
\end{tabular}


Towards Excellence: An Indexed, Refereed \& Peer Reviewed Journal of Higher Education / Dr. K M Chudasama / Page 59-78

\begin{tabular}{|l|l|c|c|c|c|c|c|c|c|c|c|}
\hline 11 & Daman \& Diu & 3 & 21 & 5 & 25 & NA & NA & NA & NA & $14^{*}$ & 13 \\
\hline 12 & Delhi & NA & NA & 6 & 30 & NA & NA & NA & NA & 2 & 7 \\
\hline 13 & Haryana & 6 & 13 & $17^{*}$ & 5 & $17^{*}$ & 13 & 10 & 27 & $15^{*}$ & 16 \\
\hline 14 & A \& N Islands & $12^{*}$ & 23 & $16^{*}$ & 18 & $13^{*}$ & 10 & 8 & 16 & $12^{*}$ & 34 \\
\hline 15 & $\begin{array}{l}\text { Andhra } \\
\text { Pradesh }\end{array}$ & 5 & 4 & $15^{*}$ & 7 & $19^{*}$ & 11 & $14^{*}$ & 13 & $23^{*}$ & 10 \\
\hline 16 & Goa & 7 & 18 & $21^{*}$ & 4 & NA & NA & NA & NA & NA & NA \\
\hline 17 & Kerala & NA & NA & 7 & 23 & NA & NA & NA & NA & $11^{*}$ & 31 \\
\hline 18 & Manipur & $19^{*}$ & 9 & $24^{*}$ & 17 & 8 & 8 & $12^{*}$ & 15 & $18^{*}$ & 24 \\
\hline 19 & Mizoram & NA & NA & $19^{*}$ & 19 & 9 & 18 & $16^{*}$ & 19 & $16^{*}$ & 2 \\
\hline
\end{tabular}

Note: * Not in Top 10. NA: Data Not Available,

However, in context of efficiency (DEA Score) as well as performance (EDI Score) Tamil Nadu turned out to be highly efficient as well as amongst top 10 performing States/Union Territories in 4 out of 5 years under analysis; while, Karnataka and Himachal Pradesh turned out to be efficient as well as amongst top 10 performing States/Union Territories in 2 out of 5 years under analysis; whereas, Gujarat, Punjab, Haryana, Andhra Pradesh and Goa turned out to be relatively efficient as well as amongst top 10 performing States/Union Territories in 1 out of 5 years under analysis. No other States/Union Territories turned out to be efficient as well as amongst top 10 performing States/Union Territories in any of the 5 years under analysis. Furthermore, it is evident from the rank correlation that there is an insignificant correlation between the Efficiency (DEA) Scores and Performance (EDI) Scores of States/Union Territories in all the 5 years under analysis. It is revealed that the States/Union Territories that depict better educational performance (in terms of Educational Development Index) need not necessarily turn out to be efficient (in terms of operations/resources allocation). Therefore, despite the States/Union Territories performing better in terms of educational attainments, optimum allocation and utilisation of resources by raising the output given input places the States'/Union Territories' Elementary School Education in a better position towards efficiency. The study allows the decision makers to develop a better understanding of the competence of Elementary School Education in States/Union Territories to provide useful insights for resource allocation, its utilisation and target attainment. 


\section{Works Cited}

Agha, S. R., Kuhail, I., Abdelnabi, N., Salem, M. and Ghanim, A. (2011). Assessment of Academic Departments Efficiency Using Data Envelopment Analysis. Journal of Industrial and Management, Vol. 4, No. 2. pp. 301-325.

Anjaneyulu, M., Nagraj, B. and Niak, S. (2006). DEA Approach for Performance Analysis of STUs. Indian Journal of Transport Management, Vol. 30, No. 4. pp. 392-409.

Asayesh, R. and Raad, F. Z. (2016). Evaluation of the Relative Efficiency of Gas Stations by Data Envelopment Analysis. International Journal of Data Envelopment Analysis and Operations Research, Vol. 1, No. 1. pp. 12-15.

Banker, R. D., Charnes, A. and Cooper, W. W. (1984). Some models for estimating technical and scale inefficiencies in data envelopment analysis. Management Science, Vol. 30. pp. 1078-1092.

Bhattacharya, A., Lovell, C. and Sahay, P. (1997). The impact of Liberalization on the Productive Efficiency of Indian Commercial Banks. European Journal of Operational Research, Vol. 98, No. 2. pp. 332-45.

Borge, L.E. and Naper, L.R. (2005). Efficiency Potential and Efficiency Variation in Norwegian Lower Secondary Schools. Working Paper Series No 12/2005 Department of Economics, Norwegian University of Science and Technology, Trondheim, Norway.

Charnes, A., Cooper, W. and Rhodes, E. (1978). Measuring the efficiency of decision making units. European Journal of Operations Research, Vol. 2. pp. 429-44.

Chudasama, K. (2010). Shipbuilding Infrastructure: An Efficiency Analysis of Indian Shipyards. The IUP Journal of Infrastructure, Vol. 8. No. 3. pp. 7-22.

Chudasama, K. (92016a). Efficiency appraisal of Indian major ports using data envelopment analysis approach. International Journal in Management and Social Science, Vol. 4, No. 9. pp. 232- 248.

Chudasama, K. (2016b). Efficiency Appraisal of Public Health Care Infrastructure in Districts of Gujarat Using Data Envelopment Analysis Approach. Paper presented at the International Seminar on Contemporary Issues in Development on December 11, 2016, Veer Narmad South Gujarat University, Surat, Gujarat. 
Chudasama, K. (2019). Secondary and Higher Secondary School Education in India: Efficiency Appraisal Using Data Envelopment Analysis Approach. Paper presented at the National Seminar on Recent Developments in Economics of Education: Policy Approaches, Issues and Innovations, January 25, 2019, Sardar Patel University, Vallabh Vidyanagar, Gujarat.

Conroy, S. J. and Arguea, N. M. (2008). An estimation of technical efficiency for Florida public elementary schools. Economics of Education Review, Vol. 27, No. 6. pp. 655-663.

Deprins, D., Simar, L. and Tulkens, H. (1984). Measuring Labor-Efficiency in Post Offices. in Marchand, M., Pestieau, P. and Tulkens, H. (eds.), The Performance of Public Enterprises: Concepts and Measurement, Elsevier Science Publishers, North-Holland.

Distexhe, V. And Perelman, S. (1994). Technical Efficiency and Productivity Growth in an era of Deregulation: The case of Airlines. Swiss Journal of Economics and Statistics, Vol. 130, No. 4. pp. 669-689.

Duncombe, W., Miner, J. and Ruggiero, J. (1997). Empirical evaluation of bureaucratic models of inefficiency. Public Choice, Vol. 93. pp. 1-18.

Eberts, R., Schwartz, E. and Stone, J. (1990). School reform, school size and student achievement. Economic Review, Vol. 26. pp. 2-15.

Farrell, M. J. (1957). The measurement of productive efficiency, Journal of the Royal Statistical Society, Vol. 120. pp. 253-290.

Isik, I. and Hassan, M. (2002). Technical, Scale and Allocative Efficiencies of Turkish Banking Industry. Journal of Banking and Finance, Vol. 26. pp. 719-766.

Kecek, G. and Demirag, F. (2016). Measurement of the Relative Efficiency of the Primary Schools in Kutahya by Data Envelopment Analysis. International Journal of Business and Social Science, Vol. 7, No. 4. pp. 265-276.

Lewin, A. Y., Morey, R. C. and Cook, T. J. (1982). Evaluating the Administrative Efficiency of Courts. Omega, Vol. 10, No. 4. pp. 401-411.

Mccarty, T. and Yaisawarng, S. (1993). Technical efficiency in New Jersey school districts. New York: Oxford University Press.

National University Of Educational Planning and Administration (2018). Elementary Education in India: Where do we stand? State Report Cards 2010-11-201617. pp. 1-112. 
National University Of Educational Planning and Administration (2018). Elementary Education in India: Progress towards UEE? Flash Statistics 2010-11-2015-16. pp. 1-68.

Nauzeer, S., Jaunky, V. and Ramesh, V. (2018). Efficiency Assessment of Secondary Schools in Mauritius: A DEA Approach. International Journal of Environmental and Science Education, Vol. 13, No. 10. pp. 865-880.

Nazarko, J. and Saparauskas, J. (2014). Application of DEA Method in Efficiency Evaluation of Public Higher Education Institutions. Technological and Economic Development of Economic, Vol. 20, No. 1. pp. 25-44.

Nguyen, K. M. and Giang, T. L. (2005). Efficiency of Construction Firms in Vietnam. Published in: Nguyen Khac Minh and Giang Thanh Long (eds.), Technical Efficiency and Productivity Growth in Vietnam: Parametric and Nonparametric Analyses. pp. 83-112.

Oum, T. and Yu, C. (1994). Economic Efficiency of Railways and Implications for Public Policy: A Comparison of the OECD Countries' Railways. Journal of Transport Economics and Policy, Vol. 28, No. 2. pp. 121-138.

Raposo, I. and Menezes, T. (2011). Public School Efficiency Using Data Envelopment Analysis: An Empirical Application for Brazil. European Regional Science Association ERSA Conference Papers, No. ERSA 11. pp. 1594.

Ray, S. 1991. Resource-Use Efficiency in Public Schools: A Study of Connecticut Data. Management Science, Vol. 37, No. 12. pp. 1620-1628.

Saricam, C., and Erdumlu, N. (2012). Evaluating efficiency levels comparatively: data envelopment analysis application for Turkish textile and apparel industry. Journal of Industrial Engineering and Management, Vol. 5, No. 2. pp. 518531.

Sigala, M. (2004). Using Data Envelopment Analysis for Measuring and Benchmarking Productivity in the Hotel Sector. Journal of Travel \& Tourism Marketing, Vol. 4. No. 2 \& 3. pp. 39-60.

Singh, A. K. (2011). Performance Evaluation of Indian Airline Industry: An Application of DEA, Asia-Pacific Business Review, Vol. 7, No. 2. pp. 92-103.

Sheikhzadeh, Y., Roudsari, A. V., Vahidi, R. G., Emrouznejad, A. and Dastgiri, S. (2012). Public and Private Hospital Services Reform Using Data Envelopment Analysis to Measure Technical, Scale, Allocative, and Cost Efficiencies. Health Promotion Perspectives, Vol. 2. No. 1. pp. 28-41. 
Tsakiridou, H. and Stergiou, K. (2014). Explaining the Efficiency Differences in Primary School Education using Data Envelopment Analysis. Journal of Education, Psychology and Social Sciences, Vol. 2. No. 2. pp. 89-96.

Tyagi, P., Yaday, S. P. and Singh, S. P. (2000). Efficiency analysis of schools using DEA: A case study of Uttar Pradesh state in India. Department of Mathematics, IIT, Roorkee,

Wober, K. W. (2007). Data Envelopment Analysis. Journal of Travel \& Tourism Marketing, Vol. 21, No. 4. pp. 91-108.

Yang, Z. (2013). Performance Analysis of Canadian Power Industry Using Data Envelopment Analysis. International Journal of Computer and Electrical Engineering, Vol. 5, No. 2. pp. 169-172.

Zhang, L. C. (2010). Measuring Elementary School Efficiency in Taipei, Taiwan: Two-Stage Data Envelopment Analysis. Paper presented at the 35th American Education Finance Association Annual Conference on March 1820th, 2010, Richmond, VA.

\section{Dr. K M Chudasama, Associate Professor, Department of Economics, Faculty of Arts, The Maharaja Sayajirao University of Baroda, Vadodara. E-mail: krishnakumar.m.c-eco@msubaroda.ac.in}

